\title{
On Middle Construction in Japanese
}

\author{
Wenchao $\mathrm{Li}^{1}$ \\ ${ }^{1}$ School of International Studies, Zhejiang University, Hangzhou, China \\ Correspondence: Wenchao Li, School of International Studies, Zhejiang University, Hangzhou, China. E-mail: \\ wideliau@gmail.com
}

Received: July 23, 2017 Accepted: August 18, 2017 Online Published: September 15, 2017

doi:10.5539/ijel.v7n6p47 URL: http://doi.org/10.5539/ijel.v7n6p47

\begin{abstract}
This study uncovers Japanese middle constructions based on the approach of "distributed morphology". The findings reveal that adjunct is obligatory in Japanese middles. Two types of grammatical elements contribute to the adjunct: suffix and adverbs. The suffix yasui corresponds to English "able". The case of the subject must be nominative, i.e., が. Once verbs are attached by the suffix yasui, their part of speech transits from verb into adjective. The new lexicon predicates an inherent property of the subject. Regarding middles with adjuncts rendered by adverbs, two subtypes are confirmed: the na-adjective formed adverb 簡単に kantan ni, and the $i$-adjective formed adverb $ょ$ yoku. The former is produced by the $n a$-adjective 簡単 with the copular に. The latter is formed by the $i$-adjective $ょ い$ with the predicate $<k u$. The mechanisms of the constructions rendered by the two are similar. Furthermore, unlike English middles, where non change-of-state verbs are ruled out, there is no distinct lexical category of middle verb Japanese. Rather, six groups of verbs are compatible: (a) motion verbs; (b) change-of-state verbs; (c) action verbs; (d) perception verbs; (e) stative verbs; and (f) accomplishment verbs. Crucially, such generosity does not result from the adjuncts. It is the "potential form" of verbs that enables psychological and perception verbs to be licensed in Japanese middles.
\end{abstract}

Keywords: middle construction, distributed morphology, Japanese

\section{Introduction}

Constructions where the verb is active in form but passive in meaning are alleged to be "middle constructions" (1a). Constructions that indicate a spontaneous event, without specifying the agentivity, are "ergative constructions" (1b). Constructions, whose syntactic external argument is not a semantic agent, are deemed "unaccusative constructions" (1c).

(1) a. The door opens $s_{\text {tran. }}$ easily. (Middle construction) (Note 1)

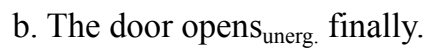

(Ergative construction)

c. The window broke.

(Unaccusative construction)

The lexical conceptual structure (LCS) of middles, unergatives and unaccusatives are provided in (2)-(4).

(2) LCS of middle construction

The door opens tran. $_{\text {easily. }}$

$\begin{array}{ccccc}x & \text { CONTROL } \\ \text { open } & \text { door } & \text { BECOME } & {\left[\begin{array}{ccc}y & \text { BE } & \text { AT- } z\end{array}\right]} & (\mathrm{x} \neq \mathrm{y}) \\ \text { open } & \end{array}$

(3) LCS of ergative construction

The door opens ${ }_{\text {unerg. }}$ finally.

$\begin{array}{llll}x & \frac{\text { CONTROL }}{\varnothing} & {\left[\begin{array}{lll}y & \text { BECOME } & {\left[\begin{array}{lll}y & \text { BE } & \text { AT }-z\end{array}\right]}\end{array}\right]} \\ & \text { door } & & \text { open }\end{array}$

(4) LCS of unaccusative construction

The window broke.

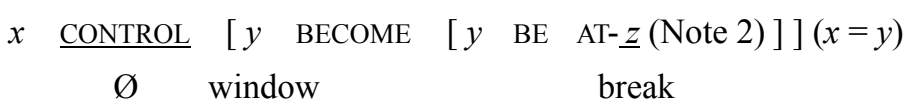


Middle construction is a unique phenomenon of the English language. Generally, it is known to bear the following characteristics.

(I) Middle construction is derived from its transitive counterpart; the subject is the original PATIENT of the verb. The original AGENT is not realised overtly, as exemplified by (5):

(5) a. People read detective stories easily. (Transitive sentence)

b. Detective stories read easily. (Middle construction)

(II) The adjunct is obligatory, as shown in (6):

(6) a. Adjunct-included

This piece of clothing washes well.

\section{b. Adjunct-less}

*This piece of clothing washes. (Note 3)

(III) Middles predicate an inherent property of the subject referent, as in (7):

(7) a. The car drives smoothly (because it is new).

b. *The car drives smoothly (because the driver is me).

The third feature leads to three restrictions:

(a) Middles do not construe the designated situation (8a);

(b) Middles are incompatible with the progressive (8b); and

(c) Psychological verbs and perception verbs in Germanic languages (Fagan, 1988; Hale \& Keyser 1987) are unlikely to denote a middle construction (9).

(8) a. *The car drives smoothly yesterday.

b. *The car is driving smoothly.

(9) Psychological verbs: admire, amuse, forget, remember. (Note 4)

*a. Birthdays/anniversaries forget easily.

*b. Geburtstage/Jubiläen vergessen leicht.

c.f. c. Geburtstage/Jubiläen vergisst man leicht.

Perception verbs: see, observe, hear.

*a. The lake sees best after rainstorm.

*b. The song hears best with the Boss speaker.

*c. Dieses Lied hört am besten mit einem Boss-Lautsprecher.

c.f. d. Dieses Lied hört man am besten mit einem Boss-Lautsprecher.

Intralinguistic variations exist even within the same language family. In German, middles appear in the form of a reflexive, and are thus morphologically distinguished from their transitive counterparts. See, for example, (10):

(10) a. Viele Leute kaufen das Buch. (transitive sentence)

b. Das Buch verkauft sich gut. (intransitive sentence)

Furthermore:

(11) Die Tür öffnet sich leicht.

The door open itself easily.

"The door opens easily."

(12) Die Kleider waschen sich gut.

These clothes wash themselves well

"These clothes wash well."

Cross-linguistic diversities are also observed. In Romance languages, the form of a reflexive seems obligatory to middles, and the agent are syntactically expressed. (13) provides an illustration: 
(13) French middles

a. Les gens lisent facilement les histoires de détectives.

b. Les histoires de détectives sont facile à lire.

Turn to Altaic languages. Intriguingly, psychological verbs and perception verbs are well accepted by Japanese middles (14). This comes to significantly differ from middles of Germanic-language.

(14) a. Psychological verbs in Japanese middles (well-formed)

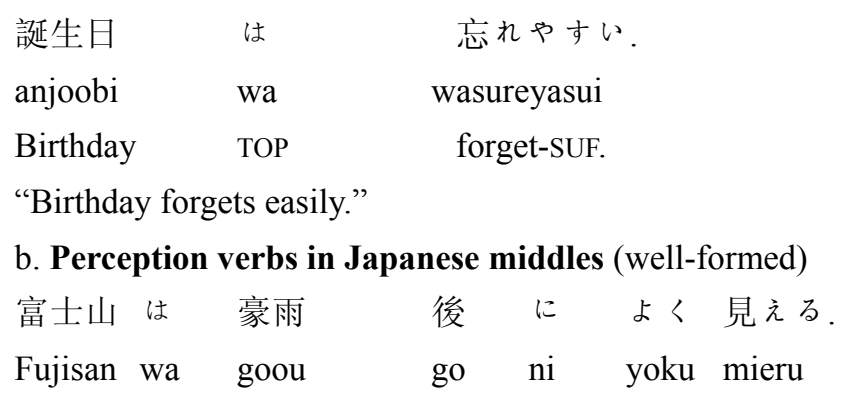

Fuji Mountain TOP heavy rain after DAT well see-UNACC

"Fuji Mountain sees better after heavy rain."

In Japanese middles, two issues in particular are worthy of discussion. First, the adjunct is obligatory. There are two grammatical items that may render a modifier: (i) the suffix やすい yasui (easily), for example (14a); and (ii) the adverb, e.g., よ < yoku (well, better, best), as in (14b). Two questions therefore arise:

(I) What role do the suffix and the adverb play in middles? Are they responsible for the well-formed middles by psychological and perception verbs?

(II) Do middles denoted by suffix and adverb display different mechanisms?

This paper is organised as follows. Section 2 introduces the "distributed morphology" approach, particularly shedding light on the Single Engine Hypothesis and the Root Hypothesis. Section 3 delves into middles conveyed by suffixes. Section 4 turns to middles conveyed by adverbs. The discussion falls into two parts. Section 4.1 focuses on middles with adjuncts conveyed by adverbs formed by the $n a$-adjective; Section 4.2 turns to middles with adjuncts conveyed by adverbs formed by the $i$-adjective. Section 5 highlights the results and concludes the paper.

The data was extracted using the Balanced Corpus of Modern Written Japanese, compiled by the National Institute for the Japanese Language and Linguistics (2011).

\section{Methodology}

Various works from different language camps have tackled middle construction for nearly a century. Initially, middle constructions were alleged to be "activo-passive sentences" by Jespersen (1927). A number of terminologies have been put forward, such as "patient-subject construction" (Lakoff, 1977); "mediopassives" (Rosta, 1995); "thematic-subject sentences" (Langacker, 1991); and "agentless actives" (Fellbaum, 1985). The approaches to middles have also varied a good deal: see the "lexical semantic" perspective (e.g., Fellbaum, 1986; Hale \& Keyser, 1987; Rosta, 1995); "lexical functional grammar" (e.g., Sioupi, 1999); and the "distributed morphology" approach (e.g., Cheng, 2016; Embick, 2004, 2010; Halle \& Marantz, 1993; Hu, 2017).

\subsection{Distributed Morphology}

The distributed morphology framework was initially put forward by Halle \& Marantz (1993; 1994). The central claim of distributed morphology lies in the "Single Engine Hypothesis" (Marantz, 1997; Arad, 2003; Embick \& Noyer, 2007).

\section{The Single Engine Hypothesis}

The formation (forming a new lexicon by combining two constituents) is a completely syntactic manipulation.

Distributed morphology has been adopted intensively in many aspects, such as English inflection and resultative construction (Embick, 2004; 2010); nominalisations (Volpe, 2005); and Hindi Noun Inflection (Singh \& Sarma, 2010). One of the common assumptions based on the approach is the "Root Hypothesis" put forward by Marantz (2001), Arad (2003), and Embick \& Noyer (2007). 


\section{The Root Hypothesis}

The syntactic categories $(\mathrm{V}, \mathrm{N}, \mathrm{A})$ are not predetermined, but are determined by an unspecified " $\sqrt{ }$ root" plus syntactic environment.

Marantz (2001, pp. 6-7) demonstrates two places for building words. One is in the domain of a root, attaching a morpheme to the root before attaching a functional head that determines the syntactic category of the word $(\mathrm{N}, \mathrm{V}$, Adj). The second place is outside the domain of functional head that determines the syntactic category.

The following sections investigate Japanese middles, posing three questions: (a) Why are psychological verbs and perception verbs licensed in middles? (b) Do middles rendered by suffixes and adverbs display syntactic distinctions? and (c) What kinds of verbs are licensed in middles or ergatives in terms of the Japanese language?

\section{Middle Constructions Rendered by Suffixes}

As touched on in Section 1, the suffix やすい yasui (denoting the ease of doing somthing) is employed in middles. Illustrations are given in (15)-(16).

$\begin{array}{rllll}\text { (15) かな } & \text { の } & \text { ほ } & \text { が } & \text { 書きやすい } \\ \text { Kana } & \text { no hoo } & \text { ga } & \text { kaki yasui } \\ \text { Kana } & \text { GEN PRON } & \text { NOM } & \text { write-easy.adj }\end{array}$

"Kana writes easily."

\section{(KOTONOHA)}

(15) implies the meaning, i.e. kana is simple, everyone can write (characters are difficult, not all the nation can write).
(16)ウエストがタプタプしてくる から 嫌でも自覚しやすい.
Westo ga taputapu shite kuru kara iya demo jikaku shi yasui
Waist NOM voluminous do-come. CONJ dislike CONC aware-do-easily.SUFF

"The waist turns voluminous, though it does not feel comfortable, it is likely for us to be aware of it."

(KOTONOHA)

The data has brought us to the point that there is no distinct lexical category of verbs with respect to middles in Japanese. Verbs of achievement perhaps are the only type ruled out by Japanese middles. Six groups of verbs seem capable of rendering a middle construction:
(a) motion verbs;
(b) change-of-state verbs;
(c) action verbs;
(d) perception verbs;
(e) stative verbs; and
(f) accomplishment verbs.

Verb types that contribute to middles and their properties are summarised in Table 1.

Table 1. Verbs of middles regarding the suffix "yasui" attachment

\begin{tabular}{cll}
\hline & Type & Property \\
\hline a. & Motion verbs: あがる, 陥る & Intransitive \\
b. & Change-of-state verbs: なる & Intransitive \\
& Change-of-state verbs: 凝固する & Transitive \\
c. & Action verbs: 書く, 掴み, 使う,たす, 犯す, 取る, & Transitive and \\
& 揮発する, 写す, やる,かかる & intransitive \\
d. & Perception verbs: 自覚する & Intransitive \\
e. & Stative verbs: わかる, 住む & Intransitive \\
f. & Accomplishment verbs: 生む & Transitive \\
\hline
\end{tabular}


In English, however, perception verbs, psychological verbs and creation verbs are absolutely ruled out. The reason, as pointed out by Levin (1993), and Nemoto \& Takeda (1993, p. 275), lies in that verbs of middles in English must involve a change of state.

After highlighting the verbs in middles, we are in a better position to investigate how the suffix "yasui" play the role of adjunct.

$\begin{array}{rllll}\text { (17) かな } & \text { の } & \text { ほう } & \text { が } & \text { 書きやすい } \\ \text { Kana } & \text { no hoo } & \text { ga } & \text { kakiyasui } \\ \text { Kana } & \text { GEN PRON } & \text { NOM } & \text { write-easy.adj }\end{array}$

\section{(KOTONOHA)}

To analyse middles conveyed by the suffix "yasui" in light of the "distributed morphology" approach, we have (18):

(18) The mechanism of the middle construction “かなのほうが書きやすい”

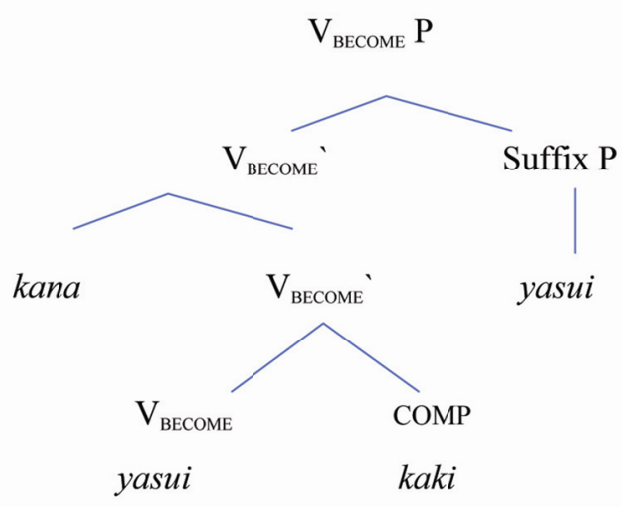

It is necessary to note that, once a verb is attached by the suffix yasui, its part of speech transits from verb into adjective. In this regard, the Japanese suffix yasui comes to resemble the English "able". For this reason, the case of the subject must be nominative: in other words, it must be $x^{3}$ rather than the accusative case particle (transitive sentence) or topic は. In the middle construction, i.e., “かなのほうが書きやすい”, the verb 書く has transited from the action verb into the adjective 書きやすい. Essentially, 書きやすい predicates an inherent property of the subject (かな), namely, "easy to write". At this stage, a syntactically and semantically perfect middle construction is built. The procedure is summarised as follows:

Transitive expression: かなを書く, the emphasis of which is placed on the action, i.e., 書く (transitive verb) $\downarrow$

Middle construction: かなのほうが書きやすい, the emphasis of which transits from action “書く” to the property of the subject “書きやすい” (adjective)

Forming a middle construction via the suffix yasui is very productive. More illustrations include: 取れやすい (easy to be taken off); 分かりやすい (easy to understand); 起こりやすい (easy to occur). In the corpus KOTONOHA, 8000 middles with adjuncts rendered by yasui have been found. Table 2 provides partial verbs that are associated with the suffix yasui. 
Table 2. Middles with adjuncts conveyed by the suffix yasui

\begin{tabular}{|c|c|c|c|}
\hline \multicolumn{2}{|l|}{ Verb } & Transitivity & Tokens \\
\hline \multicolumn{2}{|l|}{ 書き } & Transitive & 8 \\
\hline \multicolumn{2}{|c|}{ 取れ (Note 5) } & Transitive & 1 \\
\hline \multicolumn{2}{|c|}{ わかり } & Intransitive & 4 \\
\hline \multicolumn{2}{|l|}{ 起こり } & Intransitive & 1 \\
\hline \multicolumn{2}{|l|}{ かかり } & Intransitive & 1 \\
\hline \multicolumn{2}{|l|}{ 生み } & Intransitive & 1 \\
\hline \multirow{2}{*}{\multicolumn{2}{|c|}{ Sino-Japanese }} & Transitive & 1 \\
\hline & & Transitive & 1 \\
\hline \multicolumn{2}{|l|}{ あがり } & Intransitive & 1 \\
\hline \multicolumn{2}{|l|}{ pり } & Intransitive & 2 \\
\hline \multicolumn{2}{|l|}{ 掴み } & Transitive & 1 \\
\hline \multirow{2}{*}{\multicolumn{2}{|c|}{ Sino-Japanese }} & Intransitive & 1 \\
\hline & & Intransitive & 1 \\
\hline \multicolumn{2}{|l|}{ 陥り } & Intransitive & 1 \\
\hline \multirow{2}{*}{\multicolumn{2}{|c|}{ Sino-Japanese }} & Transitive & 1 \\
\hline & & Intransitive & 1 \\
\hline \multicolumn{2}{|l|}{ 使い } & Transitive & 1 \\
\hline \multicolumn{2}{|l|}{ 取り } & Transitive & 1 \\
\hline \multicolumn{2}{|l|}{ た } & Transitive & 2 \\
\hline \multicolumn{2}{|l|}{ 犯し } & Transitive & 1 \\
\hline 酸化 & Sino-Japanese & Transitive & 1 \\
\hline \multicolumn{2}{|l|}{ 流れ } & Intransitive & 1 \\
\hline \multicolumn{2}{|l|}{ 出 } & Transitive & 1 \\
\hline \multicolumn{2}{|l|}{ 固まり } & Transitive & 1 \\
\hline \multicolumn{2}{|l|}{ たまり } & Transitive & 1 \\
\hline \multicolumn{2}{|l|}{ 見失い } & Transitive & 1 \\
\hline \multirow{2}{*}{\multicolumn{2}{|c|}{ Sino-Japanese }} & Intransitive & 1 \\
\hline \multirow{2}{*}{\multicolumn{2}{|c|}{$\begin{array}{l}\text { でき } \\
\text { 食べ }\end{array}$}} & Intransitive & 1 \\
\hline & & Transitive & 1 \\
\hline
\end{tabular}

\section{Middle Constructions Conveyed by Adverb}

This section delves into middles with an adjunct conveyed by an adverb. Adverbs that modify Japanese middles include 簡単に kantan $n i$ (easy + copular), and $ょ く y o k u$ (better, best, well). The two adverbs are in fact produced from two types of adjectives, i.e., $n a$-adjective (簡単) and $i$-adjective (よい). The predicate of the $n a$-adjective is the copular $に n i$, i.e., kantan $\rightarrow$ kantan ni. The predicate of the $i$-adjective is $<k u$, i.e., yoi $\rightarrow$ yoku. (Note 6) With this in place, the following discussions will be divided into two parts: (a) middles with adjuncts conveyed by adverbs formed by the $n a$-adjective, and (b) middles with adjuncts conveyed by adverbs formed by the $i$-adjective.

\subsection{Middles with Adjuncts Conveyed by Adverbs Formed by the Na-adjective}

To begin with, the following illustrations are drawn from the corpus, where the adjuncts are conveyed by the $n a$-adjective with a copular $n i$.
(19) 髪の毛
やらゴミやらが 簡単
に取り除ける。
Kami no ke yara gomi yara ga kantan
ni torinozokeru
Hair
or rubbish or NOM easy
COP clear-remove-POT
"Hair or rubbish can easily be removed."

\section{(KOTONOHA)}

Note that the middle construction (19) is composed by a compound verb, 取り除く, in the potential form, 取り 除ける. The first event, conveyed by V1 取る toru “take", denotes the manner of the action. The second event denotes the result, and is rendered by V2, 除忛る nozokeru "remove".

Incorporating "distributed morphology", the composition of middle construction (19) can be described as follows: 
(20) The mechanism of middle construction “髪の毛やらゴミやらが簡単に取り除ける”

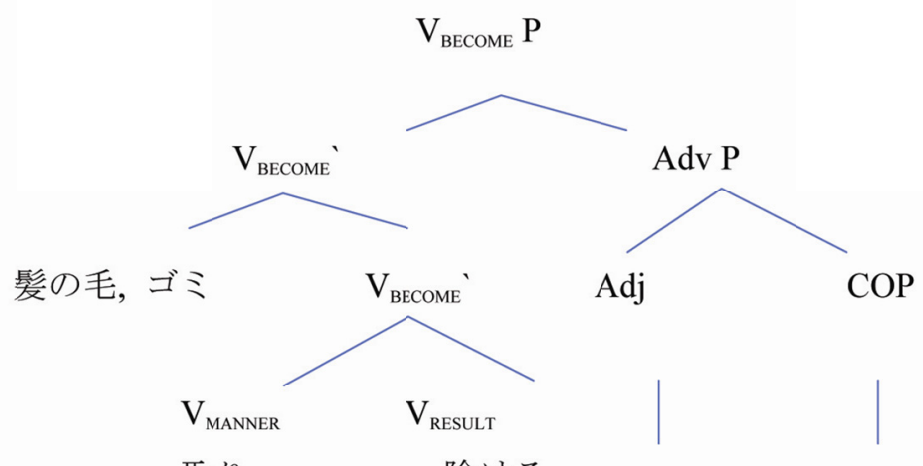

取り

除ける

簡単 に

(21) is a middle construction conveyed by a mono-verb and an adverb 簡単に:

(21) チャージはコンビニで簡単に出来ますからす权.

Chaaji wa konbini de kantan ni deki masu kara ne

Charge TOP convenient store DAT easy COPdo-POT HON because EXCL

"Charge can be easily done in the convenient store."

(KOTONOHA)

The mechanism of mono-verb middle construction is exactly the same as middles denoted by a compound verb, as in (22):

(22)

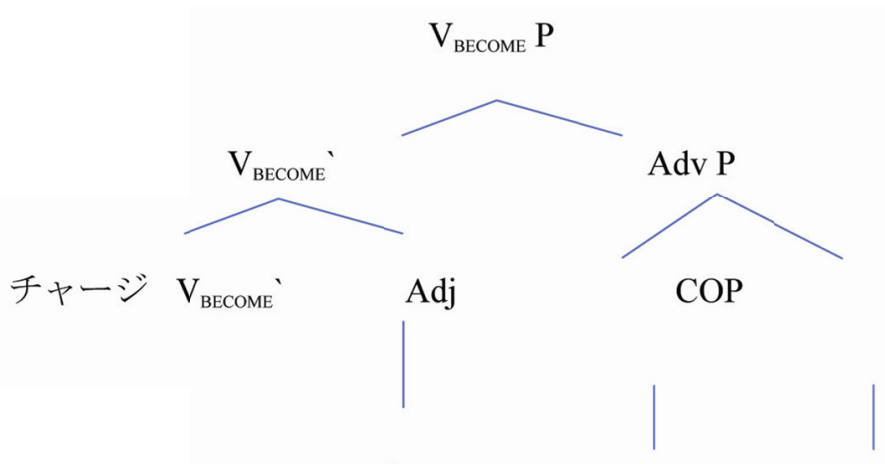

できる

簡単 に

4.2 Middles with An Adjunct Conveyed by Adverbs Formed by An I-adjective

(23) and (24) provide illustrations of middles with adjuncts rendered by adverbs formed by an $i$-adjective:

(23) 相手 の 動き もよく見える.

Aite no ugoki mo yoku mieru

Partner GEN movement foc well see-unacc

"The movement of our partner can be well observed."

(KOTONOHA)

$\begin{array}{rlllllll}\text { (24) 隣り } & 9 & \text { 運動場 } & \text { から } & \text { 子供 } & \text { の } & \text { 喚声 が よく } & \text { 聞こえる. } \\ \text { Tonari } & \text { no } & \text { undoojoo } & \text { kara } & \text { kodomo } & \text { no } & \text { kansei ga } & \text { yoku } \\ \text { kikoeru }\end{array}$ 
Next door GEN playground from children GEN shout nom well hear-unacc

"Children's shouting from the next-door playground is well heard."

\section{(KOTONOHA)}

There are 215 tokens of $く$ yoku in the database found modifying 見える mieru (be able to see), and four tokens よく yoku found modifying 聞こえる kikoeru (be able to hear). 見える and 聞こえる are unaccusative verbs, which require nominative case for the subject. The topic particle the subject only when emphasis is placed on the topic (subject).

(25) describes the mechanism of “相手の動きもよく見える” based on the distributed morphology approach:

(25) The mechanism of middle construction “相手の動きもよく見える”

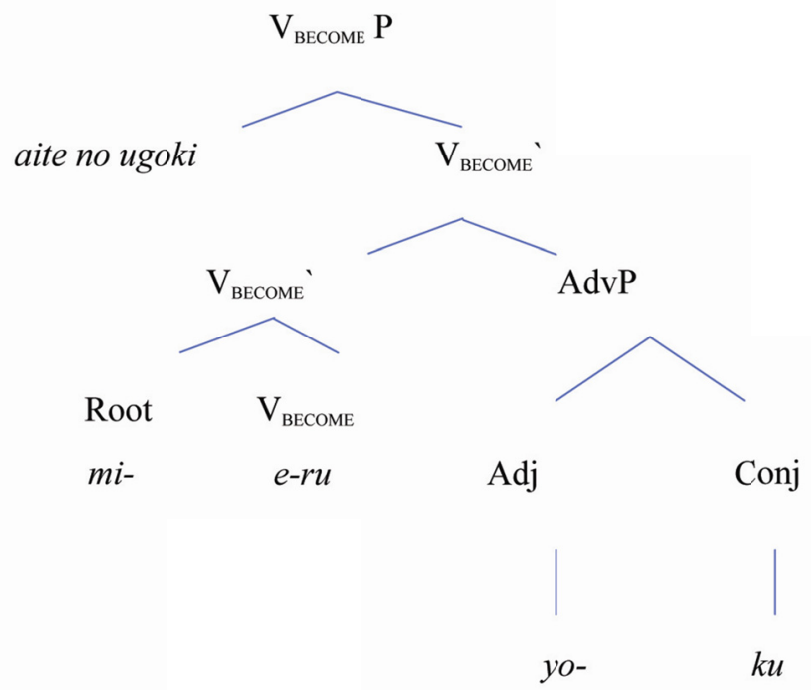

(26) provides the mechanism of “隣りの運動場から子供の喚声がよく聞こえる”:

(26) The mechanism of middle construction

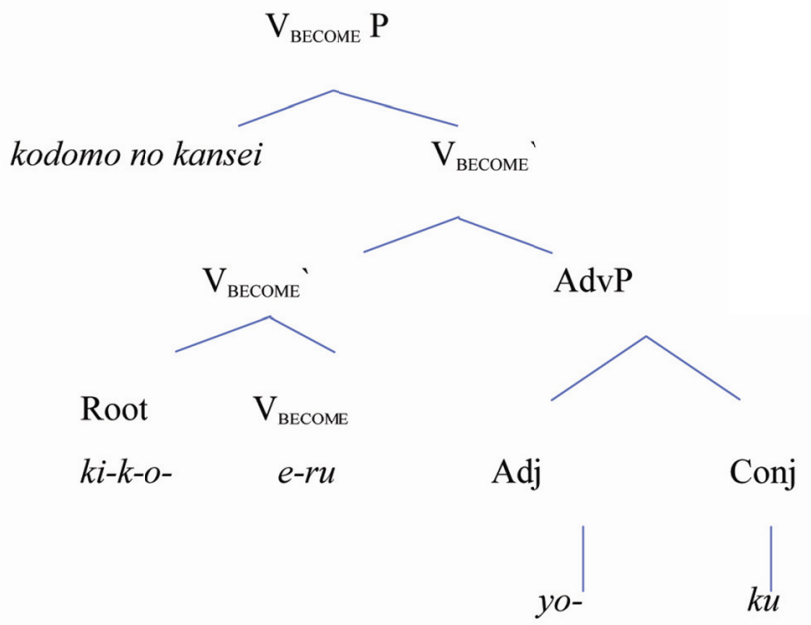

The foregoing discussions have highlighted two adverbs-based adjuncts of Japanese middles, kantan ni and yoku. To summarise, the adjunct “簡単に kantan ni (easily)” is produced by the na-adjective “簡単” with the copular “に”. The adjunct “よく yoku” is formed by the i-adjective “よい” with the predicate “く ku”. Despite some 
tiny differences, the mechanism of middle constructions rendered by the two types of adverbs are quite similar. This allows us to deduce that the acceptance of psychological and perception verbs in Japanese middles does not lie in the adjuncts. On the contrary, it is the potential form of verbs that licenses psychological and perception verbs in Japanese middles.

\section{Conclusion}

This study has uncovered Japanese middle constructions based on the approach of "distributed morphology", conveying two ways of modifying a middle construction: (a) middles modified by the suffix やすい yasui (easy to do something), and (b) middles with an adjunct conveyed by the adverbs 簡単に kantan ni (easy + copular) and $ょ<y o k u$ (better, best, well). The findings are summarised below.

(I) Unlike English middles, which only permit change-of-state verbs, there is no distinct lexical category of middle verbs with respect to middles in Japanese. A large variety of verbs seem compatible with middles: (a) motion verbs; (b) change-of-state verbs; (c) action verbs; (d) perception verbs; (e) stative verbs; and (f) accomplishment verbs. This generosity does not result from the adjuncts (suffix yasui and adverb kantan ni; yoku), but it is rather the "potential form" of verbs that enables psychological and perception verbs to be licensed in Japanese middles. Potential form is a uniqueness of the Japanese language, and now it has contributed to the uniqueness of Japanese middles (in other words, psychological and perception verbs are possible to be rendered as middles).

(II) An adjunct is obligatory in Japanese middles. Two types of grammatical elements convey the adjunct: suffixes and adverbs. The suffix yasui corresponds to the English "able". For this reason, the case of the subject

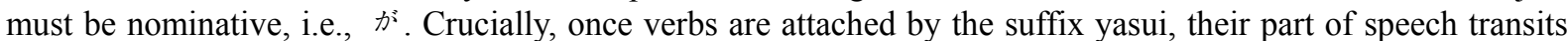
from a verb into an adjective (e.g., 書く $\rightarrow$ 書きやすい). The new lexicon predicates an inherent property of the subject, denoting a semantic meaning of "easy to do something". Thus, the focus of the expression alters from action (transitive sentence) to the inherent property of the subject (middle construction). Regarding adverbs in middles, two subtypes exist: the $n a$-adjective formed adverb and the $i$-adjective formed adverb. 簡単に kantan $n i$ is produced by the $n a$-adjective 簡単 with the copular に.よく yoku is formed by the $i$-adjective $ょ い$ with the predicate $<k u$. Essentially, the mechanisms of construction rendered by these two types of adverbs are similar.

This paper has focused on middle constructions. The Japanese language is further featured with the extensive pairs of transitive (vt) / intransitive verbs (vi). Three ways of deriving a $v t$ or a $v i$ exist:

(a) Derived from the same adjective stem;

(b) Adding a morpheme that indicates $v t$ or $v i$ properties to a stem; and

(c) Verbalising a loanword or a Japanese-originated lexicon.

$V t$ and $v i$ that share the same word form, such as verbs like hiraku (c.f. Doa o hiraku / Doa ga hiraku), are alleged to be "ergative verbs". Ergative verbs in Japanese are denoted by two types of lexicons: wago (Japanese-originated lexicon, see (27)), and kango (Sino-Japanese, see (28)):

(27) Ergative verbs (Japanese originated lexicon)

伏せる fuseru “lie down”, 振り返る furikaeru “look back”, 振舞う furumau "behave”, 構える kamaeru “gird”, 装う yosoou “dress up”, 気取る kidoru “pretend to be”, 叫ぶ sakebu “shout”, 怒鳴る donaru “shout”, 笑う warau “laugh”, 怒る okoru “get angry”.

(28) Ergative verbs (Sino-Japanese) (Note 7)

実現する jitugen suru “realize”, 污染する osen suru “pollute”, 丧失する sooshitu “loose”, 停止する teishi suru “stop”, 完成する kansei suru “complete”, 消失する shooshitu suru “vanish”, 発展する hatten suru “develop”, 倒産する toosan suru "go broke”, 爆発する bakuhatu suru “explode”, 全滅する senmetu suru “be completely destroyed", 開店する kaiten suru “open for business”, 変形する henkei suru “reshape”.

Ergative constructions by wago and kango are exemplified by (29) and (30).

\section{(29) Ergatives by wago (Japanese-originated lexicon)}

$\begin{array}{lllll}\text { a. Asakao } & \text { ga } & \text { tsuru } & \text { o } & \text { maku. } \\ \text { morning glory } & \text { NOM } & \text { tendril } & \text { ACC } & \text { roll. } \text {.TRAN }\end{array}$

"The morning glory rolled up the tendril." 
b. Asakao no tsutu ga maku.

morning glory GEN tendril NOM roll.INTR

"The tendrils of the morning glory rolled up."

(30) Ergatives by kango (Sino-Japanese)

a. Yume wo jitugen suru.

dream acc realise.tran do-support

"Realise a dream."

b. Kooyaku ga jitugen suru.

Treaty gen come true do-support

"The treaty comes true."

With this in mind, a further study on Japanese ergative constructions from a "distributed morphology" approach seem necessary, tackling the category of lexicons that are compatible with ergatives as well as the distinctions between ergatives and middles in more depth.

\section{Acknowledgment}

This paper is based on work that was supported by the National Foundation of Social Sciences (15CYY002) to Wenchao Li.

\section{References}

Arad, M. (2003). Locality constraints on the interpretation of roots. Natural Language and Linguistic Theory, 21, 736-778. https://doi.org/10.1023/A:1025533719905

Cheng, G. (2016). Study on content words: a generative grammar perspective. Journal of Anhui Normal University-Humanities and Social Sciences, (4), 416-419.

Embick, D. (2004). On the Structure of Resultative Participles in English. Linguistic Inquiry, 35, $355-392$. https://doi.org/10.1162/0024389041402634

Embick, D. (2010). Localism versus Globalism in Morphology in Morphology and Phonology. Cambridge, MA: MIT Press. https://doi.org/10.7551/mitpress/9780262014229.001.0001

Embick, D., \& Rolf, N. (2007). Distributed Morphology and the syntax/morphology interface. In G. Ramchand \& C. Reiss (Eds.), The Oxford Handbook of Linguistic Interfaces (pp. 289-324). Oxford: Oxford University Press. https://doi.org/10.1093/oxfordhb/9780199247455.013.0010

Fagan, S. (1988). The English middle. Linguistic Inquiry, 19, 181-203.

Fellbaum, C. (1985). Adverbs in agentless actives and passives. Chicago Linguistic Society, 21, 21-31.

Fellbaum, C. (1986). On the middle construction in English. Bloomington, IN: Indiana University Linguistic Club.

Hale, K., \& Keyser, J. (1987). A Aiew from the Middle, 10, 1-36. Lexicon Project Working Papers.

Halle, M., \& Alec, M. (1993). Distributed Morphology and the Pieces of Inflection. The View from Building, 20, 111-176. Cambridge, MA: MIT Press.

Halle, M., \& Alec, M. (1994). Some key features of Distributed Morphology. Papers on Phonology and Morphology, MITWPL, 21, 275-288. Cambridge, MA: MIT Working Papers in Linguistics.

$\mathrm{Hu}, \mathrm{X}$. H. (2017). On the V-qilai Middle Construction in Chinese. Workshop on the Spine of Language. Zhejiang University, Hangzhou.

Jespersen, O. (1927). A modern English grammar on historical principles, 3. London: Allen \& Unwin. Reproduced by Meicho Fukyukai, Tokyo.

Keyser, S. J., \& Roeper, T. (1984). On the middle and ergative constructions in English. Linguistic Inquiry, 15, $381-416$.

Lakoff, G. (1977). Linguistic gestalts. Chicago Linguistic Society, 13, 236-287.

Langacker, R. W. (1991). Foundations of cognitive grammar, vol. 2: Descriptive application. Stanford: Stanford University Press.

Marantz, A. (1997). No Escape from Syntax: Don't Try Morphological Analysis in the Privacy of Your Own 
Lexicon. University of Pennsylvania Working Papers in Linguistics 4.2, 201-225.

Marantz, A. (2001). Words and Things. Ms., MIT.

Rosta, A. (1995). "How does this sentence interpret?" The semantics of English mediopassives. In B. Aarts \& C. F. Meyer (Eds.), The verb in contemporary English: theory and description (pp. 123-144). Cambridge: Cambridge University Press.

Sioupi, A. (1999). The typology of middle constructions, ergative verbs and passive voice: how similar are they after all? In S. Lampropoulou (Ed.), Proceedings of the 12th International Symposium of Theoretical and Applied Linguistics, 1, 159-170. Aristotle University of Thessaloniki. Thessaloniki.

Smriti, S., \& Vaijayanthi, M. S. (2010). Hindi Noun Inflection and Distributed Morphology. Proceedings of the 17th International Conference on Head-Driven Phrase Structure Grammar Universite Paris Diderot, Paris 7 , France. CSLI Publications, 307-321. Retrieved from http://web.stanford.edu/group/cslipublications/cslipublications/HPSG/2010/singh-sarma.pdf\#search=\%27Si ngh+and+Sarma $+2010+$ Hindi+Noun+Inflection $\% 27$

Volpe, M. (2005). Japanese Morphology and its Theoretical Consequences: Derivational Morphology in Distributed Morphology. Ph.D. dissertation, Stony Brook University.

\author{
Gloss \\ CONC Concessive form \\ CONJ Conjunctive form \\ COP Copular \\ DAT Dative particle \\ EXCL Exclamatory particle \\ FOC Focus particle \\ HON Honorification \\ INTRAN. Intransitive verb \\ NEG Negation \\ POT Potential form \\ SUF. Suffix \\ TRAN. Transitive verb \\ UNERG. Unergative verb
}

\title{
Notes
}

Note 1. Middle constructions should be distinguished from pseudo middles, i.e., instrument-subject construction (1) and location-subject construction (2).

(1) a. This knife cuts well.

b. This type of pen writes scratchily.

(2) a. This lake fishes well.

b. This studio records well.

Kageyama (2001, p. 206)

Note 2. $Z$ (result) is underlined because the result is foregrounded in unaccusatives.

Note 3. Fellbaum (1986, p. 9) provides two expressions, which are adjunct-less but grammatical: (a) These chairs fold up; and (b) This dress zips up, that one buttons. In these situations, the verbs themselves have combined all the information needed to describe the subjects.

Note 4. One may argue that the psychological verb "frighten" can be compatible with middles. A search of the British National Corpus reveals that only three tokens appear in middles. An illustration might be: "You're also weak and you frighten easily" (BYU-BNC). 
Note 5. 取れる toreru is the potential form of the transitive verb 取る toru (take).

Note 6. Traditional linguists of Japanese consider $ょ く$ to be the "conjunctive form" of adjective $ょ し$.

Note 7. These 22 Sino-Japanese are drawn from Yamada (2009).

\section{Copyrights}

Copyright for this article is retained by the author(s), with first publication rights granted to the journal.

This is an open-access article distributed under the terms and conditions of the Creative Commons Attribution license (http://creativecommons.org/licenses/by/4.0/). 